\title{
Drilling to Decipher Long-Term Sea-Level Changes and Effects-A Joint Consortium for Ocean Leadership, ICDP, IODP, DOSECC, and Chevron Workshop
}

\author{
by Craig S. Fulthorpe, Kenneth G. Miller, André W. Droxler, Stephen P. Hesselbo, \\ Gilbert F. Camoin, and Michelle A. Kominz
}

doi:10.2204/iodp.sd.6.02.2008

\section{Introduction}

One of the most societally relevant objectives of the Earth sciences is to understand the history and impact of global sea-level (eustatic) fluctuations at different timescales. Over a third of the world's population lives within $100 \mathrm{~km}$ of a coastline. One-tenth of the global population and thirteen percent of the world's urban population live in coastal areas that lie within just $10 \mathrm{~m}$ above sea level (the Low Elevation Coastal Zone or LECZ), which covers only two percent of the world's land area (McGranahan et al., 2007). Reconstruction of global mean sea level since 1870 indicates a twentieth century rate of sea-level rise of $1.7 \pm 0.3 \mathrm{~mm} \mathrm{yr}-1$ and a significant acceleration of sea-level rise of $0.013 \pm 0.006 \mathrm{~mm} \mathrm{yr}-2$ (Church and White, 2006), in part due to anthropogenic influences. Satellite observations in the last decade show that the rates have increased since 1993 to $3.3 \pm 0.4 \mathrm{~mm} \mathrm{yr}^{-1}$ (Cazenave and Nerem, 2004). Remote-sensing data suggest that ice sheets currently contribute little to sea-level rise. Best estimates are that sea level could rise by as much as 50 $\mathrm{cm}$ in the next 100 years (IPCC, 2007). However, dynamical instabilities in response to climate warming may cause faster ice-mass loss (Cazenave, 2006). Rahmstorf et al (2007) show that sea-level observations are tracking at the high end of the IPCC estimates and conclude that $80 \mathrm{~cm}$, and perhaps $>1 \mathrm{~m}$, is the most likely global rise by 2100 . In some of the most heavily populated areas (e.g., the U.S. Atlantic seaboard) relative sea-level rise exceeds $4 \mathrm{~mm}^{\mathrm{yr}} \mathrm{-}^{-1}$ (Psuty and Collins, 1996) due to combined effects of global sea-level rise and subsidence. While such rates are gradual on a human timescale, the geological record shows that they can increase rapidly and dramatically (e.g., $>2 \mathrm{~m}$ in a century; Fairbanks, 1989; Bard et al., 1990); in addition, the retreat of shorelines can be erratic and rapid even under conditions of moderate global rises of sea level.

The geologic record provides an opportunity to quantify the timing, amplitudes, rates, mechanisms/controls, and effects (stratigraphic response) of eustatic change (Figs. 1 and 2). This information, in turn, provides a baseline for predicting future global sea-level changes and assessing anthropogenic influences. In order to understand the effects of potential future eustatic trends, it is vital to document how the Earth system has operated during past abrupt climate changes (e.g., the last and penultimate deglaciations) and under past conditions of extreme climate forcing, and to con- strain the eustatic response to elevated $\mathrm{CO}_{2}$ levels. For example, determining how sea level varied in response to past intervals of global warming-e.g., marine isotope chrons 5e (Thompson and Goldstein, 2005), 11 (Droxler et al., 2003), 31 (Scherer et al., 2008); "mid " Pliocene warmth (Draut et al., 2003), the middle Miocene climate optimum, the early Eocene (Zachos et al., 2001), and the Late Cretaceous (Abreu et al., 1998; Miller et al., 2005 a, b; Bornemann et al., 2008) will provide a means to evaluate the eustatic impact of future climate trends. Understanding how processes/mechanisms yield specific eustatic responses will therefore improve our understanding of the societal impact of the resulting sea-level changes. Furthermore, understanding how process interactions produce the preserved stratigraphy of beds and sequences is fundamental to deciphering the long-term geologic and climatic history recorded by sediments in a variety of marine sedimentary basins. These environments are also economically and strategically important-testing predictive sequence models has a proven potential for identifying oil and gas resources and for ground water/pollution remediation issues. Such research also helps to achieve the long-sought goal of predicting margin lithologies in the absence of drilling, a concept pioneered by the Exxon group (Vail and Mitchum, 1977). Finally, constraining the history of sea-level change provides data of direct use to researchers in other disciplines because of the relationships between

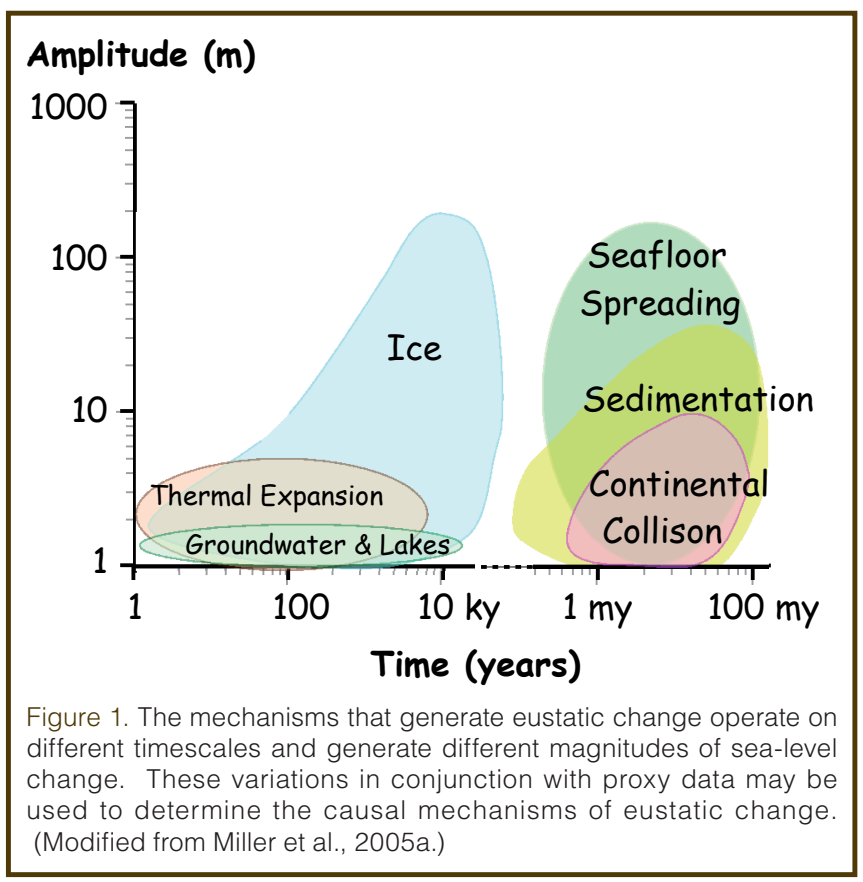


eustasy and ice-sheet growth and decay, nutrients and ocean productivity, carbon storage, and ocean chemistry.

The challenge is considerable because eustatic effects are complexly intertwined with processes of basin subsidence and sediment supply (Cloetingh et al., 1985; Karner, 1986; Posamentier et al., 1988; Christie-Blick et al., 1990; Reynolds et al., 1991; Christie-Blick and Driscoll, 1995; Kominz et al., 1998; Kominz and Pekar, 2001). Extracting the eustatic signal requires integrated onshore/offshore drilling transects involving global retrieval of cores representing multiple

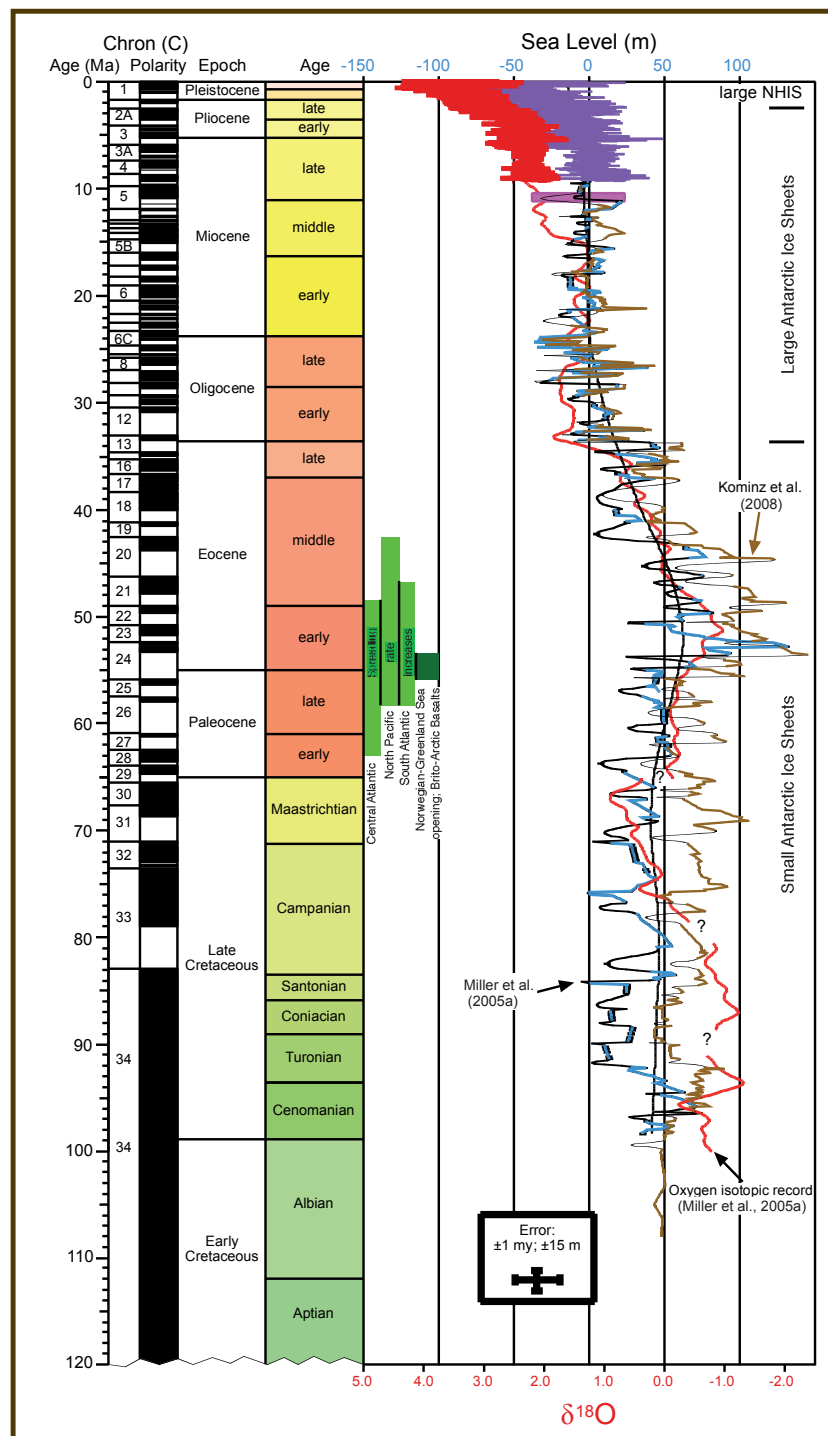

Figure 2. Global sea level (light blue) for the interval 7-100 Ma derived by back-stripping five New Jersey coastal plain core holes (Miller et al., 2005a). Revised back-stripped sea-level curve (brown) based on a total of eleven New Jersey core holes (Kominz et al., 2008). Global sea level (purple) for the interval 0-7 Ma derived from $\delta^{18} \mathrm{O}$, shown in red for a benthic foraminiferal $\delta{ }^{18} \mathrm{O}$ synthesis from $0-100 \mathrm{Ma}$ with the scale on the bottom axis (in parts per thousand, Miller et al., 2005a). The Miller et al. (2005a) back-stripped sea-level curve was smoothed with a 21-point Gaussian convolution filter to generate the smooth black curve. The pink box at $11 \mathrm{Ma}$ is a sea-level estimate derived from the Marion Plateau (John et al., 2004). Light green boxes indicate times of spreading rate increases on various ocean ridges (Cande and Kent, 1992). Dark green box indicates the opening of the Norwegian-Greenland Sea and concomitant extrusion of basalts (Modified from Browning et al., 2008). timeframes and depositional settings, including siliciclastic, carbonate, and mixed systems (Fig. 3). Fundamental to the approaches recommended by our workshop are as follows: 1) to enhance our understanding of eustatic timing, amplitudes, rates, and stratigraphic response during the icehouse period, when glacioeustasy is known to be the principal eustatic mechanism, and;2) to begin an aggressive program to understand the mechanisms responsible for greenhouse eustasy and how they relate to climatic trends and stratigraphic response.

\section{Salt Lake City Workshop}

Various groups related to the Ocean Drilling Program (ODP) have developed strategies for studying eustasy on orbital (>19 kyr) and longer timescales (Imbrie et al., 1987; Watkins and Mountain, 1990; JOIDES, 1992). These strategies have begun to be implemented with drilling transects across the New Jersey margin (ODP Legs 150, 150X, 174A, and 174AX), the Bahamas (Leg 166 and mission-specific platform sites) and a targeted sea-level amplitude experiment on the Marion Plateau, Northeast Australia (Leg 194). However, an effective, coordinated strategy requires that additional margin transects be drilled. In addition, it has been fifteen years since the last of these groups; the Sea-Level Working Group (JOIDES, 1992), discussed goals and strategies of sea-level research. Recent drilling advances, including the use of mission-specific platforms (MSP) offshore and joint onshore-offshore drilling (e.g., IODP Expedition 313), together with new views on the roles of tectonics and sediment dynamics, required that the scientific community reevaluate the fundamental assumptions of sea-level studies.

As a follow-up to the SEALAIX Symposium ("Sea-Level Changes: Records, Processes and Modeling”, September 2006, Presqu'île de Giens, France), an international workshop of more than fifty participants was held in Salt Lake City, Utah (8-10 October 2007) sponsored by Consortium for Ocean Leadership (formerly Joint Oceanographic Institutions), the International Continental Scientific Drilling Program (ICDP), the Integrated Ocean Drilling Program (IODP), Drilling, Observation and Sampling of the Earth's Continental Crust (DOSECC), and Chevron. The purposes of the workshop were 1) to review results of ODP and early IODP drilling for sea-level objectives; 2) to reevaluate principles and strategies for constraining genetic links between eustatic change and Earth system processes and for defining the relative roles of eustasy versus local processes in building the stratigraphic record; and 3) to identify possible geographical areas and time-intervals for future IODP drilling transects. Presentations about IODP, ICDP, and DOSECC were followed by keynote scientific talks and a series of short, three-minute presentations by participants. Breakout groups subsequently focused on the relationship between recorded sea-level cyclicity and eustatic mechanisms through time, and on deciphering the stratigraphic response to eustasy through a sedimentary process approach in both 

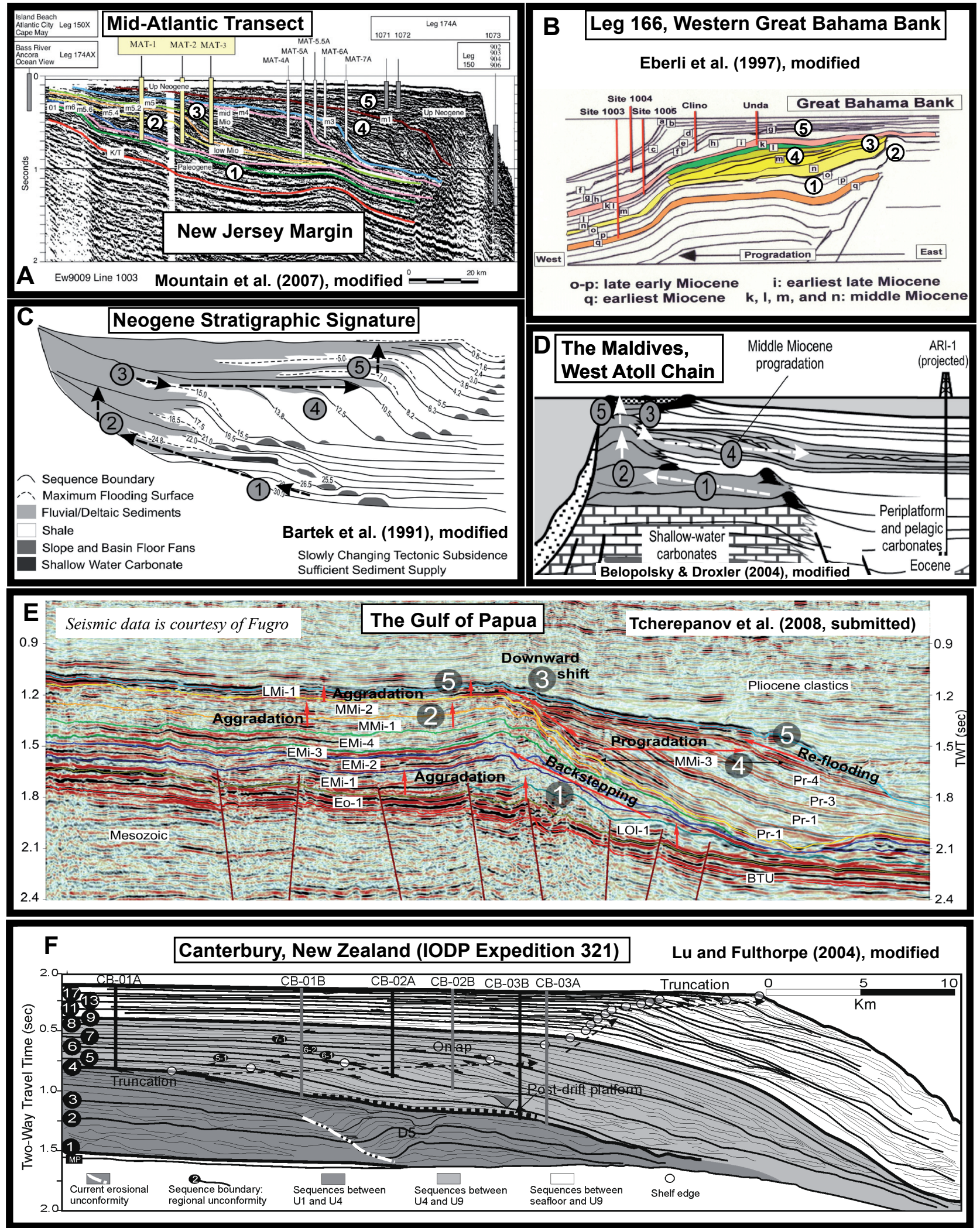

Figure 3. [A] Middle Atlantic Transect (MAT) off New Jersey, showing drillsites targeting a Paleogene-Pleistocene prograding clinoform succession. MAT has been drilled on the slope (ODP Leg 150; sites not shown) and shelf (Leg 174A; sites 1071-1073 along strike from this profile), as well as on the Coastal Plain (Legs 150X and 174AX). Inner shelf drilling (MAT 1-3) is planned as a Mission-Specific Platform IODP Expedition 213. [B] Line drawing of interpreted Great Bahama Bank sequences drilled during ODP Leg 166 (Sites 1003-1005) and the Bahamas Drilling Project (sites Clino and Unda). [C] The stratigraphic signature of the Neogene represented by: 1) late Oligocene-early Miocene aggradation, backstepping and partial drowning; 2) late early Miocene-early middle Miocene vertical growth or aggradation; 3) earliest middle Miocene downward shift of deposition; 4) late middle Miocene systematic lateral growth (progradation); and 5) late Miocene-early Pliocene re-flooding and aggradation (Bartek et al., 1991; Tcherepanov et al., 2008). [D] The Neogene stratigraphic signature along the West Maldives Inner Sea carbonate margin. [E] Neogene stratigraphic signature in the Gulf of Papua. [F] A future sea-level transect: line drawing of interpreted sequences, offshore Canterbury Basin, New Zealand, showing proposed IODP sites, scheduled for drilling as IODP Expedition 317. 
icehouse and greenhouse worlds. Breakout Group Two was further subdivided into siliciclastic and carbonate groups. In addition to identifying scientific questions and objectives, the groups were also asked to consider drilling program design, potential target areas, and technology requirements (onshore and offshore).

\section{Objective 1: Determining Eustatic Mechanisms}

Understanding the mechanisms that drive eustatic change requires knowledge of the timing, amplitudes, and rates of global sea-level change (Fig. 1). It also requires information on climate and paleoceanography, mainly derived from proxy records (Fig. 4), and tectonic mechanisms that control the volume of the oceans. In turn, such quantification of eustatic change will contribute to other areas of the Earth sciences by helping to constrain such processes as ice-sheet growth and decay, ocean temperatures, carbon burial, and inorganic carbon precipitation in carbonates (Fig. 4) as well as global

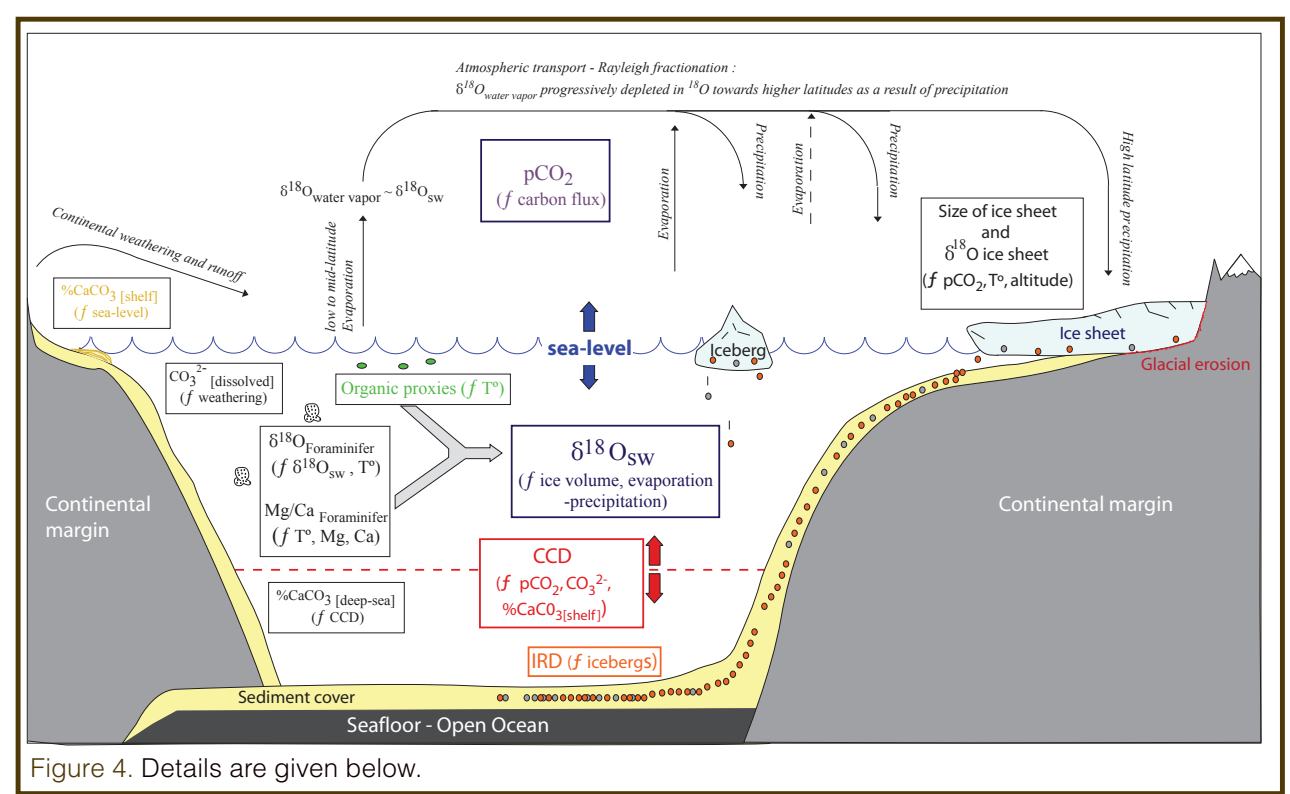

Schematic figure illustrating how deep-sea geochemical records can be used to understand mechanisms of past eustatic changes by analogy to the modern ocean. During atmospheric transport from low to high latitudes water vapor becomes progressively more depleted in $\delta^{18} \mathrm{O}$, and ice sheets have a very negative $\delta^{18} \mathrm{O}$ signature. The isotopic composition of high latitude ice sheets is a function of the magnitude of isotopic fractionation within the hydrological cycle, which in turn is dependent on $\mathrm{pCO}_{2}$ and temperature, and could vary over geological timescales. Consequently, the $\delta^{18} \mathrm{O}$ composition of seawater $\left(\delta^{18} \mathrm{O}_{\mathrm{sw}}\right)$ is largely a function $(f)$ of ice volume and regional evaporation and precipitation processes. Reconstructing $\delta^{18} \mathrm{O}_{s} \mathrm{w}$ in different ocean basins will highlight times of eustatic changes due to ice-volume fluctuations, as well as provide a record of the timing and amplitude of these changes. $\delta^{18} \mathrm{O}_{\mathrm{sw}}$ can be derived by combining the isotopic composition of foraminiferal

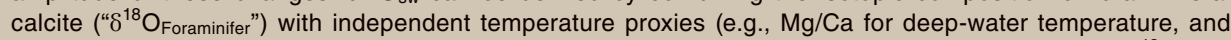
TEX86 and alkenones for surface water temperatures). Subsequently, correlation of excursions in $\delta^{18} \mathrm{O}_{\text {sw }}$ to more positive values with independent evidence of sea-level change can be taken as support for the operation of a glacio-eustatic mechanism. Open ocean sites can also provide more indirect evidences of the relative role of glacio-eustasy through geological time. The presence of ice rafted debris (IRD) in open ocean sediments indicates iceberg transport, and thus a significant volume of ice at sea level along continental margins. The waxing and waning of ice sheets is a function of high-latitude temperatures and atmospheric $\mathrm{pCO} 2$, which also impact the position of the carbonate compensation depth (CCD). Fluctuations in the CCD are recorded as variable carbonate contents $\left(\% \mathrm{CaCO}_{3}\right)$ within deep-sea sediments and could be used as indirect evidence of glacial/interglacial alternations, as CCD is sensitive to changes in carbonate burial on the shelf. Finally, eustatic variations control the area of shelf submerged, thus indirectly impacting the type of rocks subjected to continental weathering, the amount of nutrients and carbonate ions delivered to the coastal ocean, and the area available for carbon burial on continental margins. Some isotope systems ( $\mathrm{Os}, \mathrm{Nd}$, and $\mathrm{Sr}$ ) are available as proxies of continental weathering. The weathering processes ultimately have feedbacks on the carbon cycle, climate, and glacioeustasy. tectonism (Harrison, 1990). Sea level is important for the study of tectonic processes, because it is the datum against

1) Refining timing, amplitudes, and mechanisms of icehouse (Oligocene-Recent) eustatic change. ODP results to date have demonstrated that global sea-level changes over the past 42 addressed the timing of sea-level change and has also determined that sequence boundaries indeed represent timelines as predicted in the sequence stratigraphic model (Eberli

However, our understanding of how climate change influences sea level, even during this "icehouse" period of large ice sheets, is incomplete. In particular, there are still uncertainties surrounding the hierarchy of eustatic and sequence arly the origins of sequences with durations of $>1$ myr, which do not appear to conform to long-period (1.2 myr and 2.4 myr) astronomical variations (Miller et al., 2005a). It is surprising that modulation by the 1.2-myr-long tilt cycle is not a dominant periodicity in icehouse sea-level records, because it has been shown that the short 41-kyr tilt cycle dominates the ice-volume record of the past 34+ my (Zachos et al., 2001). The 2.4-myr very long eccentricity cycle dominates carbon isotopic records throughout the Cretaceous to Cenozoic through its effects on the carbon system, which might be expected to be influenced by sea-level changes. Spectral analysis of the Miller et al. (2005a) sea-level records shows that variations occur with an as-yet-unexplained, persistent 3 -myr beat that may be either an interference between the $1.2 \mathrm{myr}$ and 2.4 myr cycles or be an artifact of an undersampled sea-level signal. This intriguing relationship bears investigation because the million-year-scale sea-level signal can be shown to be a composite of 41-kyr tilt cycles, at least for the icehouse world (Miller et al., 2005a).

Moreover, sea-level amplitudes during this period have not yet 
been adequately constrained. One approach for determining eustatic amplitudes that has been applied with success to the New Jersey margin involves combining sequence stratigraphic and back-stripping analyses (Fig. 5; Kominz and Pekar, 2001; 2002; Pekar and Kominz, 2001). The resulting sea-level curve (Fig. 2; Browning et al., 2008) represents the best current estimate, but it is still incomplete because lowstand sediments were not recovered, introducing uncertainty to estimated amplitudes. Possibly as a result, the Miocene part of the New Jersey sea-level curve does not appear to correspond as well to the globally recognized stratigraphic signature
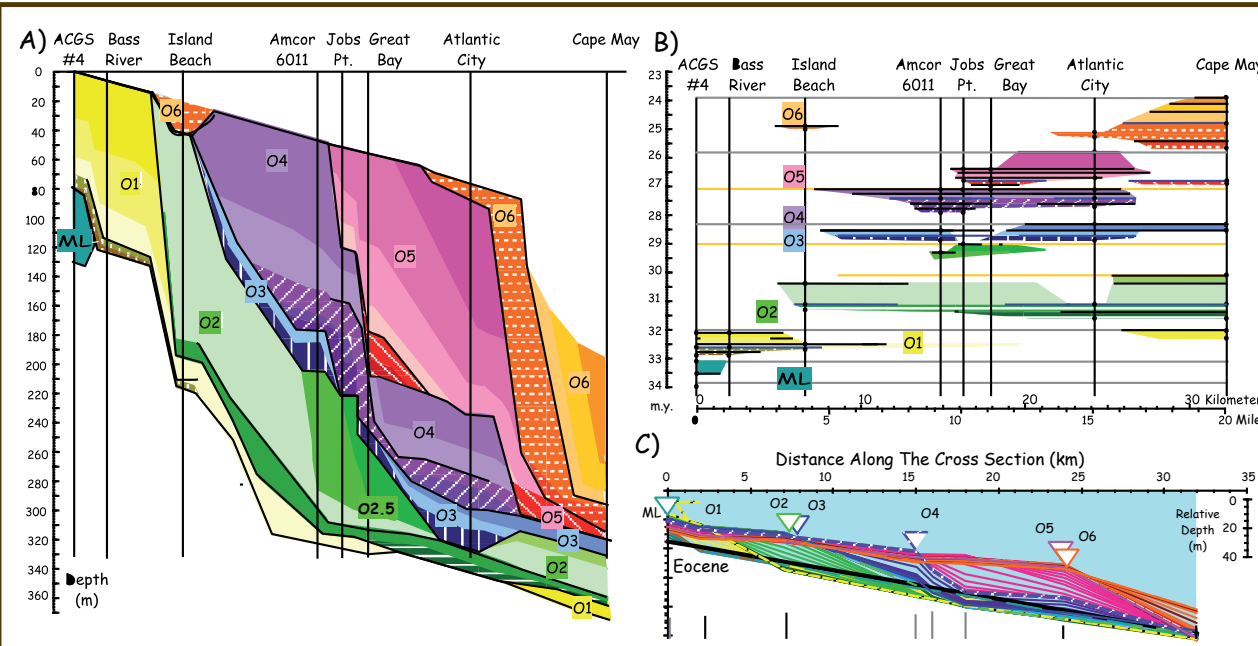

Figure 5. In order to determine sea-level change from a marginal marine setting, we recommend at least two-dimensional sequence stratigraphic back-stripping. An example of some of the data required for two-dimensional sequence stratigraphic back-stripping from Kominz and Pekar $(2001,2002)$ is shown for illustration. [A] Chronostratigraphic chart for New Jersey coastal plain Oligocene sequences. Solid colors represent highstand systems tracts, while lowstand systems tracts are depicted by patterned colors. Vertical lines show well control. [B] Sequence model for New Jersey coastal plain Oligocene sequences. Patterns and lines as described above. [C] Geometry of horizons identified in A and B after performing geohistory analysis. Sequences may be identified by colors, which reflect those in A and B, and the labeled offlap break points (inverted triangles) of the final horizon of each sequence. (Modified from Kominz and Pekar, 2002.) of the Neogene as other eu-

static curves (Fig. 6; Bartek et al., 1991). Furthermore, the New Jersey curve also differs from $\delta 18 \mathrm{O}$ records that have been corrected for paleotemperature and are therefore an improved record of ice-volume fluctuations (Billups and Schrag, 2002; Lear et al., 2004), and which do correspond well to the stratigraphic signature of the Neogene (Fig. 6).

Finally, estimates of the amplitudes of eustatic change from one-dimensional back-stripping at one location (e.g., New Jersey; Miller et al., 2005a; Kominz et al., 2008; Browning et al., 2008) requires supplemental application of this procedure to strata on distant continents (e.g., Carter et al., 1991). Future scientific drilling must therefore include additional drilling for icehouse eustatic objectives. Ideally, two- and three-dimensional back-stripping procedures would improve amplitude estimates (Kominz and Pekar, 2001). These approaches require good regional seismic coverage and a well-constrained, regional, sequence stratigraphic framework, including data that can only be obtained from cores.

2) Challenging the paradigm of a stable, ice-free "greenhouse" climate. Though we are beginning to unlock the mysteries of icehouse sea-level changes, our understanding of eustatic change during the preceding "greenhouse" world of the Triassic to early Eocene is controversial. For example, the Late Cretaceous has been reconstructed as a greenhouse world with warm polar climates (Bice et al., 2006), and most studies have assumed the absence of polar ice sheets (e.g., Huber et al., 1995). However, the work of Exxon Production Research Company (Vail and Mitchum, 1977; Haq et al., 1987) and more recent publications (Van Sickel et al., 2004; Miller et al., 2003, 2005a, b; Bornemann et al., 2008) have indicated large (tens of meters), short-period ( $<1$ myr) Late Cretaceous global sea-level (eustatic) fluctuations (Fig. 2). In addi-
Figure 6. Oxygen isotopic and eustatic curves showing correspondence to the stratigraphic signature of the Neogene (red arrows and numbers 1-5; see Figure 3). The Miller et al. (2005a) eustatic curve from the New Jersey margin does not conform precisely to the global signature, particularly in the middle and late Miocene. 
tion, second- ( $10 \mathrm{my})$, third- (1-5 my) and fourth- $(\sim 0.5 \mathrm{my})$ order sequences can apparently be correlated widely between tectonically active and passive regions (e.g., Western Interior Seaway, Europe and India; Gale et al., 2002) suggesting eustatic control. Glacioeustasy is the only known mechanism for producing such large, rapid eustatic changes (Donovan and Jones, 1979; Fig. 1).

There are two solutions to this enigma: eustatic mechanisms are not fully understood, or there were ice sheets throughout much of the Triassic to early Eocene (Stoll and Schrag, 1996, 2000; Abreu et al., 1998; Miller et al., 2003, 2005a,b; Bornemann et al., 2008). ODP and ICDP drilling onshore New Jersey (Leg 174AX) have provided a detailed record of Cretaceous to early Eocene sequences. This record quantifies high amplitudes and rates of eustatic change $(>25 \mathrm{~m}$ in $<1 \mathrm{myr}$ ) in the Late Cretaceous to Eocene greenhouse world. Based on this sea-level history, Miller et al. (2003, 2005a, b) have proposed that ice sheets existed for geologically short intervals (i.e., lasting $\sim 100 \mathrm{ky}$ ) during the Late Cretaceous-Eocene. This view can be reconciled with previous assumptions of an ice-free Greenhouse World. Eustatic changes on the $10^{6} \mathrm{yr}$ scale were typically $\sim 15-30 \mathrm{~m}$ in the Late Cretaceous-Eocene (ca. 100-33.8 Ma), suggesting growth and decay of small- to medium-sized $\left(10-15 \times 10^{6} \mathrm{~km}^{3}\right)$ ephemeral Antarctic ice sheets (Miller et al., 2005a, b).

However, although such indirect evidence for ephemeral ice sheets is growing, there is, as yet, no physical evidence for Late Cretaceous to early Eocene ice sheets. A particular difficulty is that other data indicate warm global temperatures for much of this interval-for example, very warm Albian-Santonian sea surface temperatures in the tropical Atlantic (Forster et al., 2007). There is therefore a need for additional high-resolution stratigraphic records from the greenhouse period.

\section{Objective 2: Defining Stratigraphic Responses}

The stratal geometries that define sedimentary sequences worldwide (Mitchum et al., 1977; Haq et al., 1987) result from a complex interplay of processes acting in three dimensions. Eustasy competes with climatic and paleoceanographic variations, tectonism, rates and modes of sediment supply, and submarine current activity to influence base level and shoreline position and, hence, stratal formation and preservation. Understanding margin sedimentation, therefore, requires evaluation of multiple processes (including eustasy) at various temporal and spatial scales (Nittrouer and Kravitz, 1995). However, predictive models of the distribution of sediments within unconformity-bounded sequences are based on assumptions about the importance of relative sea-level change (Posamentier et al., 1988; Vail et al., 1991) that have yet to be adequately tested.
Nevertheless, various industry and academic studies have established that unconformity-bounded sequences are indeed the building blocks of the stratigraphic record (see summary in Christie-Blick and Driscoll, 1995), as first proposed by Vail and Mitchum (1977), and that they can occur in predictable patterns (Fig. 3). For example, the geometric signature of stratigraphic sequences along continental margins for the last 30 Ma involves (Fig. 3C-E) (1) late Oligocene (Chattian) and early Miocene (Aquitanian) aggradation, back-stepping and drowning; (2) late early Miocene (Burdigalian) and earliest middle Miocene (early Langhian) aggradation; (3) earliest middle Miocene (late Langhian) downward shift of deposition; (4) middle Miocene (Serravallian) progradation; and (5) two stacked flooding and aggradational episodes in the late Miocene (Tortonian) and early Pliocene (Zanclean) separated by a late Miocene (Messinian) downward shift of deposition (Bartek et al., 1991, Tcherepanov et al., 2008a and b). Although this pattern is widespread and is observed globally in both siliciclastics and carbonates (Fig. 3; Bartek et al., 1991; Tcherepanov et al., 2008a and b), the heart of this section, the early and middle Miocene, has not yet been ground-truthed by drilling. The fundamental assumptions and predictive capabilities of sequence models can only be tested by drilling on shallow continental shelves where (3-D) sedimentary geometries are constrained by seismic data (e.g., Kominz and Pekar, 2002).

Siliciclastic Margins. Because of the complex interplay of forcing mechanisms responsible for the stratigraphic record, stratigraphic response must be defined in a diversity of time periods and settings, both tectonic and sedimentary. Siliciclastic sediments are excellent sea-level markers because both highly sensitive indicators of shoreline position, and they are globally widespread. However, it is essentialto define the specific sedimentary processes (depositional, transportational, and erosional) responsible for the stratigraphic record and to distinguish the responses of these processes to eustasy from their responses to local forcing. This process-based approach must be a component of future drilling-based sea-level research.

The stratigraphic record comprises both surfaces and intervening sedimentary units. In offshore work, surfaces are often defined initially using seismic reflection profiles and later calibrated by coring (Fig. 3). However, only coring can provide the lithofacies and biofacies of the intervening units. Sequence stratigraphic models of such units (Posamentier et al., 1988; Van Wagoner et al., 1988; Vail et al., 1991) are based on simple assumptions about how facies respond to relative sea-level changes. However, the real world is rendered more complex by the additional influence of local forcing and the three-dimensionality of sequence architectures. Future drilling to investigate the stratigraphic response to eustasy must therefore evaluate the contributions of tectonism and sediment supply. In addition, geometrical variations must be constrained by pre-drilling seismic surveys. 
Carbonate Platforms and Margins. Carbonates are excellent sea-level markers because carbonate facies are depthdependent owing to the importance of sunlight to many carbonate-secreting organisms (Eberli et al., 1997; Camoin et al., 2007a). The relationship of these systems to the carbon cycle allows direct correlation of climatic and eustatic signals (Lear et al., 2004). In addition, multiple dating techniques are available for carbonates (including ${ }^{14} \mathrm{C}, \mathrm{U} / \mathrm{Th}, \mathrm{Sr}, \mathrm{U} / \mathrm{Pb}$, biostratigraphy, and magnetostratigraphy). These enable examination of a wide range of frequencies of sea-level change, from millennial scale to tens of millions of years.

Continental margin transects (Fig. 3) have the advantage that their stratigraphic architectures are well constrained by seismic data. However, they are complemented by tropical reefs and atolls, which provide the most reliable geological estimates of relative sea level by dating "fossil sunshine" (e.g., shallow dwelling corals). The study of coral reefs is of crucial importance in attempts to resolve the rates of millennial-scale changes in sea level, to clarify the mechanisms that drive glacial-interglacial cycles, and to constrain geophysical models. Coral reefs provide unparalleled records of sea-level amplitudes, particularly for the middle to late Pleistocene. For example, drilling reefs in Barbados has provided a precise estimate for the last eustatic lowstand $(120 \pm 5 \mathrm{~m}$ below present at $18 \mathrm{ka}$; Fairbanks, 1989; Bard et al., 1990; Peltier and Fairbanks, 2006). Shallow-water drilling of coral reefs remains challenging due to recovery problems, but is necessary to allow study of recent high-resolution climate changes, and it contributes to estimates of the future behavior of the Earth system on societal timescales. This approach was employed during IODP Expedition 310 off Tahiti (Camoin et al., 2007a, b).

\section{Strategies}

1) A focus on both icehouse and greenhouse objectives.

2) Drilling transect approach. This approach, which was tried and tested on the New Jersey Margin and Great Bahama Bank, with additional IODP drilling planned off New Zealand (Fig. 3), must be enhanced and extended by:

- Integration of onshore (e.g., ICDP, DOSECC) and offshore (IODP, DOSECC) drilling. The record of icehouse eustasy is best preserved offshore (e.g., on continental margins), but the older, greenhouse, record tends to be preserved and drillable beneath coastal plains or in onshore basins (e.g., the Western Interior Seaway). Onshore drilling is therefore expected to play an increasingly important role in sea-level studies.

- Drilling of sufficient boreholes, including multiple transects where necessary, and incorporation of sufficient seismic control to constrain three-dimensional stratigraphic architecture.
- Maximizing core recovery by using appropriate drilling technology (e.g., casing, mud) and platforms (e.g., Mission Specific Platforms [MSPs]), and by adapting coring strategies as needed, e.g., by using diamond coring or short advances of the XCB.

3) Recognizing the value of addressing tectonically active settings. For example, the stratigraphic expression of sea-level change in active foreland basins in the U.S. and Canadian western interior basins is superlative, though the stratigraphic records incorporate the effects of both eustasy and tectonism.

4) Incorporating a focus on high-resolution (10 $3-10^{5} \mathrm{yr}$ ) glacial-interglacial cycles (e.g., the last $130 \mathrm{kyr}$ ). Examination of margins with high stratigraphic resolution will allow evaluation of the interaction of eustasy and other processes (e.g., Papua New Guinea; Jorry et al., 2008), and integration with process-oriented modeling (e.g., physical and mathematical modeling done as part of the Margins and Intermargins Initiatives).

5) Coordination with drilling operations designed to address other objectives. Sea-level studies can benefit greatly from the results of research into, for example, paleoclimate, carbon cycling, and ice-sheet dynamics (Fig. 4). Conversely, these research programs will also gain necessary insights from a well constrained eustatic history.

\section{Future Work}

Future IODP drilling for sea-level objectives includes IODP Expedition 313, New Jersey inner shelf drilling scheduled for summer 2009 and IODP Expedition 317, Canterbury Basin, New Zealand, scheduled for November 2008-January 2009. Great Barrier Reef drilling is tentatively planned for 2009. These planned expeditions, and existing IODP proposals (e.g., Maldives, North West Australian Shelf, Gulf of Mexico - Southern Bank, Belize margin, Gulf of Papua), all address icehouse objectives. Such drilling is indeed vital, in particular to constrain icehouse eustatic amplitudes and to calibrate the stratigraphic signature of the Neogene (Bartek et al., 1991). However, the next phase of sea-level studies must include greenhouse objectives. We therefore encourage proponents to prepare and submit sea-level proposals for both offshore and onshore drilling focusing on the greenhouse world.

\section{Acknowledgements}

We thank all of the workshop participants for their contributions in support of scientific drilling for sea-level objectives. Particular thanks are due to breakout group chairs Andy Gale, John Jaeger, Michelle Kominz, Rick Sarg, and Bill Thompson. Charna Meth and Julie Farver of the 
Consortium for Ocean Leadership provided excellent support before and during the workshop. Dave Zur of DOSECC also provided logistical support. Bryan Bracken of Chevron led an outstanding field trip to Book Cliffs before the workshop, ably assisted by Sunday Shephard and Peter Sixsmith. We express our sincere appreciation for the financial support of the Consortium for Ocean Leadership, ICDP, IODP, DOSECC, and Chevron. This joint support enabled us to make the workshop a truly international meeting.

\section{References}

Abreu, V.S., Hardenbol, J., Haddad, G., Baum, G.R., Droxler, A.W., and Vail, P.R., 1998. Oxygen isotope synthesis: A Cretaceous ice-house? In Graciansky, P.-C., Hardenbol, J., Jacquin, T., and Vail, P.R. (Eds.), Mesozoic and Cenozoic Sequence Stratigraphy of the European Basins. Tulsa, Okla. (SEPM (Society for Sedimentary Geology)) Spec. Pub. 60:75-80.

Bard, E., Hamelin, B., and Fairbanks, R.G., 1990. U-Th ages obtained by mass spectrometry in corals from Barbados: Sea level during the past 130,000 years. Nature, 346:456-458, doi: 10.1038/346456a0.

Bartek, L.R., Vail, P.R., Anderson, J.B., Emmet, P.A., and Wu, S., 1991. Effect of Cenozoic ice sheet fluctuations in Antarctica on the stratigraphic signature of the Neogene. J. Geophys. Res., 96:6753-6778, doi:10.1029/90JB02528.

Belopolsky, A.V., and Droxler, A.W., 2004. Seismic expressions of prograding carbonate bank margins: Middle Miocene progradation in the Maldives, Indian Ocean. AAPG Mem., 81:267-290.

Betzler, C., Kroon, D., and Reijmer, J.J.G., 2000. Synchroneity of major late Neogene sea-level fluctuations and paleoceanographically controlled changes as recorded by two carbonate platforms. Paleoceanogr., 15:722-730, doi:10.1029/ 1999PA000481.

Bice, K.L., Birgel, D., Meyers, P.A., Dahl, K.A., Hinrichs, K., and Norris, R.D., 2006. A multiple proxy and model study of Cretaceous upper ocean temperatures and atmospheric $\mathrm{CO}_{2}$ concentrations. Paleoceanogr., 21:PA2002, doi: 10.1029/2005PA001203.

Billups, K., and Schrag, D.P., 2002. Paleotemperature and ice-volume of the past $27 \mathrm{Myr}$ revisited with paired $\mathrm{Mg} / \mathrm{Ca}$ and 180/16O measurements on benthic foraminifera. Paleoceanogr., 17(1):26-37, doi:10.1029/2000PA000567.

Bornemann, A., Norris, R.D., Friedrich, O., Beckmann, B., Schouten, S., Damsté, J.S.S., Vogel, J., Hofmann, P., and Wagner, T., 2008. Isotopic evidence for glaciation during the Cretaceous super greenhouse. Science, 319:189-192, doi:10.1126/ science.1148777.

Browning, J.V., Miller, K.G., Sugarman, P.J., Kominz, M.A., McLaughlin, P.P., and Kulpecz, A.A., 2008. A 100 million year record of sequences, sedimentary facies and sea-level change from Ocean Drilling Program onshore core holes, U.S. Mid-Atlantic coastal plain. Basin Res., in press, doi:10.1111/j.1365-2117.2008.00360.x

Camoin, G.F., Iryu, Y., McInroy, D., and the Expedition 310 scientists, 2007a. Proc. IODP, 310. College Station, Texas (Integrated
Ocean Drilling Program - Management International, Inc.).

Camoin, G.F., Iryu, Y., McInroy, D., and the Expedition 310 scientists, 2007b. IODP Expedition 310 reconstructs sea-level, climatic and environmental changes in the South Pacific during the last deglaciation. Sci. Drill., 5:4-12.

Cande, S.C., and Kent, D.V., 1992. A new geomagnetic polarity time scale for the Late Cretaceous and Cenozoic. J. Geophys. Res., 97:13917-13951, doi:10.1029/92JB01202.

Carter, R.M., Abbott, S.T., Fulthorpe, C.S., Haywick, D.W., and Henderson, R.A., 1991. Application of global sea-level and sequence stratigraphic models in southern hemisphere Neogene strata from New Zealand. In MacDonald, D. (Ed.), Sea Level and Active Plate Margins, International Association of Sedimentologists Spec. Pub. 12:41-65.

Cazenave, A., 2006. How fast are the ice sheets melting? Science, 314:1250-1252, doi:10.1126/science.1133325.

Cazenave, A., and Nerem, R.S., 2004. Present-day sea-level change: Observations and causes. Rev. Geophys., 42:RG3001, doi: 10.1029/2003RG000139.

Christie-Blick, N., and Driscoll, N.W., 1995. Sequence stratigraphy. Annu. Rev. Earth Planet. Sci., 23:451-478, doi:10.1146/ annurev.ea.23.050195.002315.

Christie-Blick, N., Mountain, G.S., and Miller, K.G., 1990. Seismic stratigraphic record of sea-level change. In Revelle, R. (Ed.), Sea-level Change, Washington, DC (National Academy Press), 116-140.

Church, J.A., and White, N.J., 2006. A 20th century acceleration in global sea-level rise. Geophys. Res. Lett., 33:L01602, doi:10.1029/2005GL024826.

Cloetingh, S., McQueen, H., and Lambeck, K., 1985. On a tectonic mechanism for regional sea-level variations. Earth Planet. Sci. Lett., 75:157-166, doi:10.1016/0012-821X(85)90098-6.

Donovan, D.T., and Jones, E.J.W., 1979. Causes of world-wide changes in sea level. J. Geol. Soc. London, 136:187-192, doi:10.1144/gsigs.136.2.0187.

Draut, A.E., Raymo, M.E., McManus, J.F., and Oppo, D.W., 2003. Climate stability during the Pliocene warm period. Paleoceanogr., 18(4):1078, doi:10.1029/2003PA000889.

Droxler, A., Poore, R., and Burckle, L., 2003. Earth's climate and orbital eccentricity: The marine isotope stage 11 question. Geophysical Monograph Series, 137.

Eberli, G.P., 2000. The record of Neogene sea-level changes in the prograding carbonates along the Bahamas transects-166 syntheses. In Swart, P.K., Eberli, G.P., Malone, M.J., and Sarg, J.F., (Eds.), Proc. ODP Sci. Results, 166. College Station, Texas (Ocean Drilling Program), 167-177.

Eberli, G., Swart, P., Malone, M., and Shipboard Scientific Party, 1997. Leg 166 Preliminary Report, College Station, Texas (Ocean Drilling Program).

Fairbanks, R.G., 1989. Glacio-eustatic record 0-16,000 years before present: Influence of glacial melting rates on Younger Dryas event and deep ocean circulation. Nature, 34:637-642, doi:10.1038/342637a0.

Forster, A., Schouten, S., Baas, M., and Sinninghe Damsté, J.S., 2007. Mid-Cretaceous (Albian-Santonian) sea surface temperature record of the tropical Atlantic Ocean. Geology, 35:919922; doi: 10.1130/G23874A.1

Gale, A.S., Hardenbol, J., Hathway, B., Kennedy, W.J., Young, J.R., and Phansalkar, V., 2002. Global correlation of Cenomanian 
(Upper Cretaceous) sequences: Evidence for Milankovitch control on sea level. Geology, 30:291-294; doi: 10.1130/00917613(2002) 030<0291:GCOCUC >2.0.CO;2

Haq, B.U., and Al-Qahtani, A.M., 2005. Phanerozoic cycles of sealevel change on the Arabian Platform. GeoArabia, 10:127-160.

Haq, B.U., Hardenbol, J., and Vail, P.R., 1987. Chronology of fluctuating sea levels since the Triassic (250 million years ago to present). Science, 235:1156-1167.

Harrison, C.G.A., 1990. Long-term eustasy and epeirogeny in continents. In Revelle, R. (Ed.), Sea-level Change, Washington, DC (National Academy Press), 141-158.

Huber, B.T., Hodell, D.A., and Hamilton, C.P., 1995. Mid to Late Cretaceous climate of the southern high latitudes: stable isotopic evidence for minimal equator-to-pole thermal gradients. Geol.Soc.Am.Bull.,107:1164-1191, doi:10.1130/00167606(1995)107<1164:MLCCOT>2.3.CO;2.

Imbrie, J. et al., 1987. Scientific goals of an Ocean Drilling Program designed to investigate changes in the global environment. In Report of the Second Conference on Scientific Ocean Drilling (COSOD II), Joint Oceanographic Institutions for Deep Earth Sampling, 15-46.

Intergovernmental Panel on Climate Change (IPCC), 2007. Climate change 2007-Synthesisreport.Summaryforpolicymakers. Available at http://www.ipcc.ch/pdf/assessment-report/ ar4/syr/ar4_syr_spm.pdf.

John, C.M., Karner, G.D., and Mutti, M., 2004. Delta $18 \mathrm{O}$ and Marion Plateau back-stripping: combining two approaches to constrain late middle Miocene eustatic amplitude. Geology, 32:829-832, doi:10.1130/G20580.1.

JOIDES, 1992. Sea-Level Working Group (SLWG) Report. Loutit, T. S. (Ed.), JOIDES Journal, 18(3):28-36.

Jorry, S.J., Droxler, A.W., Mallarino, G., Dickens, G.R., Bentley, S.J., Peterson, L.C., and Opdyke, B., 2008. Bundled turbidite deposition in the Central Pandora Trough (Gulf of Papua) since Last Glacial Maximum: Linking sediment nature and accumulation to sea-level fluctuations at millennial timescale. J. Geophys. Res., 113:F01S19, doi:10.1029/ 2006JF000649.

Karner, G.D., 1986. Effects of lithospheric in-plane stress on sedimentary basin stratigraphy. Tectonics, 5:573-588, doi:10.1029/ TC005i004p00573.

Kominz, M.A., and Pekar, S.F., 2001. Oligocene eustasy from twodimensional sequence stratigraphic backstripping. Geol. Soc. Am. Bull., 113:291-304, doi:10.1130/00167606(2001)113<0291:OEFTDS>2.0.CO;2.

Kominz, M.A., and Pekar, S.F., 2002. Sequence stratigraphy and eustatic sea level, Proceedings 22nd Annual GCSSEPM Foundation Bob F. Perkins Research Conference, "Sequence Stratigraphic Models for Exploration and Production: Evolving Methodology, Emerging Models and Application Case Histories”, 8-11 August 2002, Houston, Texas, 349-365.

Kominz, M.A., Miller, K.G., and Browning, J.V., 1998. Cenozoic sealevel estimates from back-stripping. Geology, 26:311-314.

Kominz, M., Browning, J.V., Miller, K.G., Sugarman, P.J., Misintseva, S. and, Scotese, C.R., 2008. Late Cretaceous to Miocene sea-level estimates from the New Jersey and Delaware Coastal Plain core holes: An error analysis. Basin Research, in press.

Lear, C.H., Rosenthal, Y., Coxall, H.K., and Wilson, P.A., 2004. Late Eocene to early Miocene ice sheet dynamics and the global carbon cycle. Paleoceanogr., 19(4):PA4015, doi:10.1029/ 2004PA001039.

Liesicki, L.E., and Raymo, M.E., 2005. A Pliocene-Pleistocene stack of 57 globally distributed d $18 \mathrm{O}$ records. Paleoceanography, 20, PA1003, doi:10.1029/2004PA001071.

Lu, H., and Fulthorpe, C.S., 2004. Controls on sequence stratigraphy of a middle-Miocene to Recent, current-swept, passive margin: offshore Canterbury Basin, New Zealand. Geol. Soc. Am. Bull., 116:1345-1366, doi:10.1130/B2525401.1.

McGranahan, G., Balk, D., and Anderson, B., 2007. The rising tide: assessing the risks of climate change and human settlements in low elevation coastal zones. Environment and Urbanization 19:17-37, doi:10.1177/0956247807076960.

Miller, K.G., Kominz, M.A., Browning, J.V., Wright, J.D., Mountain, G.S., Katz, M.E., Sugarman, P.J., Cramer, B.S., ChristieBlick, N., and Pekar, S.F., 2005a. The Phanerozoic record of global sea-level change. Science, 310:1293-1298, doi:10.1126/science.1116412.

Miller, K.G., Mountain, G.S., the Leg 150 Shipboard Party, and Members of the New Jersey Coastal Plain Drilling Project, 1996. Drilling and dating New Jersey Oligocene-Miocene sequences: ice volume, global sea level, and Exxon records. Science, 271:1092-1094, doi:10.1126/science.271.5252. 1092.

Miller, K.G., Sugarman, P.J., Browning, J.V., Kominz, M.A., Hernandez, J.C., Olsson, R.K., Wright, J.D., Feigenson, M.D., and Van Sickel, W., 2003. A chronology of Late Cretaceous sequences and sea-level history: Glacioeustasy during the Greenhouse World. Geology, 31:585-588, doi:10.1130/0091-7613(2003)031<0585:LCCOLR>2.0.CO;2.

Miller, K.G., Wright, J.D., and Browning, J.V., 2005b. Visions of ice sheets in a greenhouse world. In Paytan, A., and De La Rocha, C. (Eds.), Ocean Chemistry Throughout the Phanerozoic, Marine Geology, Special Issue, 217:215-231.

Mitchum, R.M., Jr., Vail, P.R., and Thompson, S., 1977. Seismic stratigraphy and global changes of sea level, part 2: the depositional sequence as a basic unit for stratigraphic analysis. In Payton, C.E., (Ed.), Seismic Stratigraphy - Applications to Hydrocarbon Exploration, AAPG Memoir 26:53-62.

Mountain, G.S., Burger, R.L., Delius, H., Fulthorpe, C.S., Austin, J.A., Jr., Goldberg, D.S., Steckler, M.S., McHugh, C.M., Miller, K.G., Monteverde, D.H., Orange, D.L., and Pratson, L.F., 2007. The long-term stratigraphic record on continental margins. In Nittrouer, C.A., Austin, J.A., Jr., Field, M.E., Kravitz, J.H., Syvitski, J.P.M., and Wiberg, P.L. (Eds.), Continental Margin Sedimentation: From Sediment Transport to Sequence Stratigraphy, International Association of Sedimentologists Special Publication 37:381-458.

Nittrouer, C.A., and Kravitz, J.H., 1995. Integrated continental margin research to benefit ocean and earth sciences. Eos 76:121, $124,126$.

Pekar, S.F., and Kominz, M.A., 2001. Two-dimensional paleoslope modeling: A new method for estimating water depths for benthic Foraminiferal biofacies and paleo shelf margins. $J$. Sed. Res., 71:608-620, 2001, doi:10.1306/100600710608.

Peltier, W.R. and Fairbanks, R.G., 2006. Global glacial ice volume and 
Last Glacial Maximum duration from an extended Barbados sea-level record. Quat. Sci. Rev., 25:3322-3337, doi:10.1016/j.quascirev.2006.04.010.

Posamentier, H.W., Jervey, M.T., and Vail, P.R., 1988. Eustatic controls on clastic deposition I -- Conceptual framework. In Wilgus, C.K., Hastings, B.S., Kendall, C.G.St.C., Posamentier, H.W., Ross, C.A., and Van Wagoner, J.C. (Eds.), Sea-Level Changes: An Integrated Approach, SEPM Spec. Publ. 42:109-124.

Psuty, N.P., and Collins, D., 1996. Sea-level rise: A white paper on the measurements of sea-level rise in New Jersey and a perspective on the implications for management. Coastal Hazard Management Report, Office of Land and Water Planning, New Jersey Department of Environmental Protection.

Rahmstorf, S., Cazenave, A., Church, J.A., Hansen J.E., Keeling, R.F., Parker, D.E., and Somerville, R.C.J., 2007. Recent climate observations compared to projections. Science, 316:709, doi:10.1126/science.1136843.

Reynolds, D.J., Steckler, M.S., and Coakley, B.J., 1991. The role of the sediment load in sequence stratigraphy: The influence of flexural isostasy and compaction. J. Geophys. Res., 96:69316949, doi:10.1029/90JB01914.

Scherer, R.P., Bohaty, S.M., Dunbar, R.B., Esper, O., Flores, J.A., Gersonde, R., Harwood, D.M., Roberts, A.P., and Taviani, M., 2008. Antarctic records of precession-paced insolationdriven warming during early Pleistocene Marine Isotope Stage 31. Geophys. Res. Lett., 35:L03505, doi:10.1029/ 2007GL032254.

Stoll, H., and Schrag, D.P., 2000. High resolution stable isotope records from the upper Cretaceous of Italy and Spain: glacial episodes in a greenhouse planer? Geol. Soc. Am. Bull., 112:308-319, doi:10.1130/0016-7606(2000)112<0308: $\mathrm{HRSIRF}>2.3 . \mathrm{CO} ; 2$.

Stoll, H.M., and Schrag, D.P., 1996. Evidence for glacial control of rapid sea-level changes in the early Cretaceous. Science, 272:1771-1774, doi:10.1126/science.272.5269.1771.

Tcherepanov, E.N., Droxler, A.W., Lapointe, P., Dickens, G.R., Bentley, S.J., Beaufort, L., Peterson, L.C., Daniell, J., and Opdyke, B.N., 2008a. Neogene evolution of the mixed carbonatesiliciclastic system in the Gulf of Papua, Papua New Guinea. J. Geophys. Res., 11:F01S21, doi:10.1029/2006JF000684.

Tcherepanov, E.N., Droxler, A.W., Lapointe, P., and Mohn, K., 2008b. Carbonate seismic stratigraphy of the Gulf of Papua mixed depositional system: Neogene stratigraphic signature and eustatic control. Basin Res., 20(2): 185-209, doi:10.1111/ j.1365-2117.2008.00364.x

Thompson, W.G., and Goldstein, S.L., 2005. Coral dating that corrects for exchange of uranium decay products with sea water reveals that sea level varied repeatedly by up to 30 meters during recent glaciations. Science, 308:401-404.

Vail, P.R., and Mitchum, R.M., Jr., 1977. Seismic stratigraphy and global changes of sea level, Part 1: Overview. In Payton, C.E. (Ed.), Seismic Stratigraphy-Applications to Hydrocarbon Exploration. Am. Assoc. Petrol. Geol. Memoir 26:51-52.

Vail, P.R., Audemard, F., Bowman, S.A., Eisner, P.N., and Perez-Cruz, C., 1991. The stratigraphic signatures of tectonics, eustasy and sedimentology—an overview. In Einsele, G., Ricken,
W., and Seilacher, A. (Eds.), Cycles and events in stratigraphy, Berlin (Springer-Verlag), 617-659.

Van Sickel, W.A., Kominz, M.A, Miller, K.G., and Browning, J.V., 2004. Late Cretaceous and Cenozoic sea-level estimates back-stripping analysis of borehole data, onshore New Jersey. Basin Res., 16:451-465, doi:10.1111/j.13652117.2004.00242.x.

Van Wagoner, J.C., Posamentier, H.W., Mitchum, R.M., Vail, P.R., Sarg, J.F., Loutit, T.S., and Hardenbol, J., 1988. An overview of the fundamentals of sequence stratigraphy and key definitions. In Wilgus, C.K., Hastings, B.S., Kendall, C.G.St.C., Posamentier, H.W., Ross, C.A., and Van Wagoner, J.C. (Eds.), Sea-level Changes: An Integrated Approach. SEPM Spec. Publ. 42:39-45.

Watkins, J.S., and Mountain, G.S., 1990. Role of ODP drilling in the investigation of global changes in sea level. JOI-USSAC Workshop Rept., El Paso, Texas, 24-26 October 1988, 70 p.

Zachos, J., Pagani, M., Sloan, L., Thomas, E., and Billups, K., 2001. Trends, rhythms, and aberrations in global climate $65 \mathrm{Ma}$ to Present. Science, 292:686-693, doi:10.1126/science. 1059412.

\section{Authors}

Craig S. Fulthorpe, The University of Texas at Austin Institute for Geophysics, John A. and Katherine G. Jackson School of Geosciences, J.J. Pickle Research Campus, Bldg. 196 (ROC), 10100 Burnet Road (R2200), Austin, Texas 787584445, U.S.A., e-mail: craig@ig.utexas.edu.

Kenneth G. Miller, Department of Earth and Planetary Sciences, Wright Labs, Rutgers, The State University of New Jersey, 610 Taylor Road, Piscataway, N.J. 08854-8066, U.S.A.

André W. Droxler, Department of Earth Science, Rice University, P.O. Box 1892, Houston, Texas 77251-1892, U.S.A.

Stephen P. Hesselbo, Department of Earth Sciences, University of Oxford, Parks Road, Oxford OX1 3PR, U.K.

Gilbert F. Camoin, CEREGE UMR 6635 CNRS, BP 80, Europôle Méditerranéen de l'Arbois, F-13545 Aix-enProvence cedex 4, France.

Michelle A. Kominz, Department of Geosciences, Western Michigan University, 1133 Rood Hall, 1903 West Michigan Avenue, Kalamazoo, Mich., 49008, U.S.A. 